\title{
Real-world monitoring of BNT162b2 vaccine-induced SARS-CoV-2 $B$ and $T$ cell immunity in naive healthcare workers: a prospective single center study
}

1 Bas Calcoen ${ }^{1}$, Kim Callebaut ${ }^{2}$, Aline Vandenbulcke ${ }^{1}$, Nico Callewaert ${ }^{2}$, Xavier Bossuyt $^{3}$, 2 Johan Van Weyenbergh ${ }^{4}$, Piet Maes ${ }^{4}$, Maya Imbrechts ${ }^{5}$, Thomas Vercruysse ${ }^{6}$, Hendrik Jan 3 Thibaut $^{6}$, Dorinja Zapf ${ }^{7}$, Kersten Dieckmann ${ }^{7}$, Karen Vanhoorelbeke ${ }^{1,5}$, Nick Geukens ${ }^{\mathbf{5}}$, 4 Simon De Meyer ${ }^{1}$, Wim Maes ${ }^{5 *}$

$6{ }^{1}$ Laboratory for Thrombosis Research, KU Leuven campus Kulak Kortrijk, Kortrijk, Belgium

$7 \quad{ }^{2}$ AZ Groeninge Hospital, Department of Laboratory Medicine, Kortrijk, Belgium

$8{ }^{3}$ Department of Microbiology, Immunology and Transplantation, KU Leuven and Department of 9 Laboratory Medicine, University Hospitals Leuven, Leuven, Belgium

$10{ }^{4}$ Laboratory for Clinical and Epidemiological Virology, KU Leuven Rega Institute, Leuven,

11 Belgium

$12{ }^{5}$ PharmAbs, The KU Leuven Antibody Center, KU Leuven, Leuven, Belgium,

13 ' ${ }^{6}$ Laboratory of Virology and Chemotherapy KU Leuven Rega Institute, Leuven, Belgium

$14{ }^{7}$ Institut für experimentelle Immunologie, EUROIMMUN Medizinische Labordiagnostika AG , 15 Lübeck, Germany

17 * Correspondence:

18 Wim Maes

19 wim.maes@kuleuven.be

20 Keywords: SARS-CoV-2, BNT162b2 vaccine, real-world monitoring, $B$ and T cell response, 21 breakthrough infection, naive healthcare workers. 
medRxiv preprint doi: https://doi.org/10.1101/2022.01.17.22269081; this version posted January 17, 2022. The copyright holder for this preprint

(which was not certified by peer review) is the author/funder, who has granted medRxiv a license to display the preprint in perpetuity.

\section{healthcare workers}

All rights reserved. No reuse allowed witholthermission vaccine monitoring in naive

\section{Abstract}

23 Background: Severe acute respiratory syndrome coronavirus 2 (SARS-CoV-2) is the cause of the 24 ongoing COVID-19 pandemic. To prevent the massive COVID-19 burden, several vaccination 25 campaigns were initiated. We performed a single center observational trial to evaluate adaptive 26 immunity in naive healthcare workers upon BNT162b2 vaccination.

27 Methods: Serological analysis was performed through conventional immunoassays. Antibody 28 functionality was analyzed via in vitro neutralization assays. Circulating receptor-binding domain

29 (RBD) specific B cells were assessed via flowcytometry. The induction of SARS-CoV-2 specific

30 T cells was investigated through interferon $-\gamma$ release assay combined with flowcytometric profiling

31 of activated CD4 and CD8 T cells.

32 Results: Three months after vaccination, all but one of the subjects $(\mathrm{N}=31)$ displayed vaccine33 induced neutralizing antibodies. In 10 out of 31 subjects, circulating RBD specific B cells were 34 found of which the rate showed moderate correlation to serological parameters. Specific interferon$35 \gamma$ release was present in all subjects and correlated with the significant upregulation of CD69 on 36 CD4+ and CD8+ T cells and CD40L on CD4+ T cells. Interestingly, no relation was found between 37 B and $\mathrm{T}$ cell parameters. In addition, one symptomatic breakthrough infection with the SARS-

38 CoV-2 alpha variant of concern was reported.

39 Conclusion: Three months post vaccination, both humoral and cellular immune responses are 40 detectable in all but one participant. No correlation was found between the magnitude of both B 41 and $\mathrm{T}$ cell responses. 
medRxiv preprint doi: https://doi.org/10.1101/2022.01.17.22269081; this version posted January 17, 2022. The copyright holder for this preprint

(which was not certified by peer review) is the author/funder, who has granted medRxiv a license to display the preprint in perpetuity.

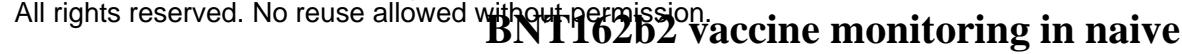

\section{healthcare workers}

\section{$42 \quad 1 \quad$ Introduction}

43 Back in December 2019, multiple cases with serious pneumonia of unknown origin (later renamed as coronavirus disease 19 or COVID-19) were described in Wuhan, China (1). Not long afterwards, the causative pathogen was identified via real-time polymerase chain reaction (RT-PCR) as a novel sarbecovirus (sub-genus of the $\beta$-coronaviridae) and named severe acute respiratory syndrome coronavirus 2 (SARS-CoV-2) $(2,3)$.

Within a few weeks, SARS-CoV-2 rapidly spread internationally and on 30 January 2020, the world health organization (WHO) declared the outbreak a public health emergency of international concern (4). As a result, many countries introduced strict socio-economic rules (e.g. lockdown, mouth mask) to limit viral spreading and prevent a total collapse of their healthcare system (5).

During the pandemic, multiple strategies including the development of a SARS-CoV-2 vaccine were urgently initiated to lower the massive SARS-CoV-2 related burden. Multiple vaccine development strategies were explored, including nucleic acid-based (e.g. BNT162b2 or Comirnaty $^{\circledR}(6,7)$, mRNA-1732 or Spikevax $\left.{ }^{\circledR}(8,9)\right)$, adenovector-based (e.g. Vaxzevria ${ }^{\circledR}(10)$, COVID19 vaccine Janssen ${ }^{\circledR}(11,12)$ ) and protein-based (Sanofi-GSK ${ }^{\circledR}(13)$ ) vaccines of which several products received conditional authorization by either the European Medical Agency (EMA) or Food and Drug Administration (FDA) at the end of 2020. This resulted in the roll-out of international vaccination campaigns at an unprecedented scale and speed.

However, due to the emergence of several SARS-CoV-2 variants of concern (VoC) that already led to new infection waves around the globe $(14,15)$, there is reasonable concern whether the immune response evoked by the currently available vaccines is sufficient to cover these VoC. For example, it is known that several of these SARS-CoV-2 VoC have mutations within their spike (S) protein or receptor-binding domain (RBD) region and therefore could be able to escape functionally active vaccine-induced antibodies that only bind to unique epitopes present on Wuhan strain S or RBD (16). In addition, only a limited number of studies reveal mid-term (i.e. longer than 2 months post mRNA vaccination) sustainability data of vaccine-induced de novo responses to SARS-CoV-2 within healthy subjects $(17,18)$. Finally, most vaccine monitoring studies are often solely based on the evaluation of serological responses (19), although it is known from for example vaccination against smallpox that specific $\mathrm{T}$ cells can be detected up to 75 years after vaccination and thus are crucial for long-term immunity $(20,21)$. Indeed, few groups have looked at both vaccine-induced $\mathrm{B}$ and $\mathrm{T}$ cell immunity, in particular in healthy SARS-CoV-2-naive volunteers $(22,23)$ as most trials focused on either immunocompromised or SARS-CoV-2 convalescent patients. Concerning specific $\mathrm{T}$ cell responses upon mRNA-based SARS-CoV-2 vaccination, available data are limited to phase I/II studies (24) of the Comirnaty ${ }^{\circledR}$ vaccine and studies that either assessed short-term $\mathrm{T}$ cell response (i.e. up to one month after booster vaccination) $(25,26)$ or focused on $\mathrm{T}$ cell responses upon prime or boost vaccination $(27,28)$. Of note, there are several, sometimes contradictory reports concerning both the occurrence rate $(29,30)$ and severity $(31,32)$ of post mRNA vaccination breakthrough infections (BTI) .

80 To address these gaps, we monitored vaccine elicited B and T cell responses in a real-world setting. 81 Hereto, SARS-CoV-2 naive healthcare workers were followed for three months after vaccination 82 with the BNT162b2 SARS-CoV-2 vaccine (Comirnaty ${ }^{\circledR}$ ) in a prospective single center study. 


\section{healthcare workers}

\section{Materials and Methods}

\section{$84 \quad 2.1 \quad$ Study design}

85

\subsubsection{Recruitment}

During January 2021, professional healthcare workers from the supraregional AZ Groeninge hospital (Kortrijk, Belgium) qualified to receive the BNT162b2 (Comirnaty ${ }^{\circledR}$ ) vaccine were contacted via the hospital's newsletter for voluntary enrollment in this study. Healthcare workers were included after signing an informed consent form. Participants were excluded if they met at least one of the following criteria: severe acute infection of any kind, pregnancy, primary immunodeficiency (PID), chronic treatment with immunomodulatory agents (e.g. anti-TNF- $\alpha$ agents, corticosteroids), documented earlier natural infection with SARS-CoV-2 or positive serology (including either anti-S IgG, anti-S IgA or anti-nucleocapsid (N) IgG) found at baseline sampling.

\subsubsection{Sampling}

A baseline sampling moment prior to vaccination was performed either one day before or on the day of prime vaccination $\left(\mathrm{t}_{\mathrm{pre}}\right)$. Comirnaty ${ }^{\circledR}$ administration was performed as indicated by the manufacturer and upon the recommendation by the Belgian Superior Health Council. A second sampling was performed three months after $t_{\text {pre }}\left(t_{3 m}\right)$. In case a participant, after receiving two vaccines, presented with COVID-19 symptoms (e.g. dry cough, fever and/or headache) and was positive for SARS-CoV-2 via real-time polymerase chain reaction (RT-PCR), he/she was considered to experience a symptomatic BTI. In this situation, additional sampling was scheduled as soon as possible ( $\left.\mathrm{t}_{\mathrm{BTI}}\right)$. Sampling details are visualized in Figure 1.

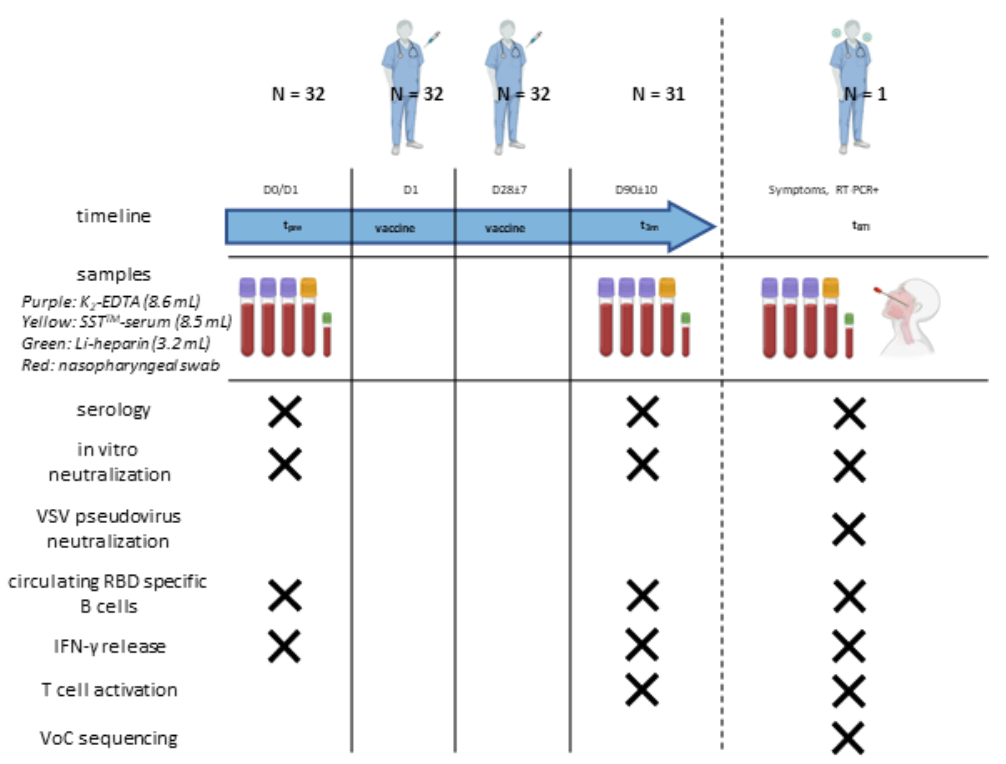

Figure 1. Study design and timeline. A total of 32 healthcare workers were enrolled. One day before or on the day of the first BNT162b2 vaccine, a first baseline sampling moment was scheduled $\left(\mathrm{t}_{\text {pre }}\right)$. A second sampling moment $\left(\mathrm{t}_{3 \mathrm{~m}}\right)$ was planned between 80-100 days after baseline. 


\section{healthcare workers}

109 On each moment, serum was collected to determine SARS-CoV-2 serology and neutralization 110 efficacy whereas blood was used both for isolating PBMCs to detect circulating RBD specific B 111 cells and to assess both SARS-CoV-2 specific T cell activity and IFN- $\gamma$ release. When a participant 112 developed symptoms and was tested positive via RT-PCR after receiving two vaccines, an 113 additional sampling moment was planned ( $\left.\mathrm{t}_{\mathrm{BTI}}\right)$. At $\mathrm{t}_{\mathrm{BTI}}$, a nasopharyngeal swab was collected to 114 execute viral whole genome sequencing. Also, a VSV pseudovirus neutralization assay was additionally performed at this timepoint. Abbreviations: PBMC $=$ peripheral blood mononuclear cells, IFN- $\gamma=$ interferon $\gamma$, RT-PCR $=$ real-time polymerase chain reaction, VSV = vesicular stomatitis virus, $\mathrm{VoC}=$ variants of concern. This figure was created using Biorender (www.biorender.com).

\subsubsection{Serum and peripheral blood mononuclear cell (PBMC) isolation}

Venous blood from three $\mathrm{K}_{2}$-EDTA tubes was used to isolate PBMCs via density gradient isolation with Ficoll (lymphoprep ${ }^{\mathrm{TM}}$, STEMCELL technologies, Norway) using SepMate tubes (STEMCELL technologies, Norway). PBMCs were diluted in $90 \%$ fetal calf serum containing 10 $\%$ DMSO, divided in aliquots and stored in liquid nitrogen after a controlled cooling procedure. When needed, PBMC aliquots were shortly thawed at $37{ }^{\circ} \mathrm{C}$ and washed two times in dPBS $\left(\right.$ Gibco $^{\mathrm{TM}}$ Life Sciences, Thermo Fisher Scientific, USA) with a centrifugation step at $300 \mathrm{~g}$ for 7 min at $4{ }^{\circ} \mathrm{C}$ after each washing. Serum was collected from the $\mathrm{SST}^{\mathrm{TM}}$ II Advance tubes and stored at $-20{ }^{\circ} \mathrm{C}$.

\subsubsection{Ethical approval}

This clinical trial was registered at the EU Clinical Trial Register with ID 2021-001304-15. This trial was performed according to the declaration of Helsinki and was approved by both the local Ethical Committee of the AZ Groeninge hospital (B3962021000022) and the Belgium Federal Agency of Drugs and Health Products (FAGG; protocol no. AZGS2021005).

\subsection{Serological parameters}

\subsubsection{Anti-S IgA and IgG assay}

Serum anti-S IgA antibodies were measured with the Anti-SARS-CoV-2 IgA enzyme immunoassay from EUROIMMUN (Lübeck, Germany) on an ETI-Max 3000 instrument from DiaSorin (Saluggia, Italy). Following the instructions from the manufacturer, samples with a cutoff index greater or equal to 1.1 were labeled as positive. Serum anti-S IgG titers were measured with the VIDAS SARS-COV-2 IgG (9COG) enzyme immunoassay from Biomérieux (Marcyl'Etoile, France) on a VIDAS 3 instrument from the same manufacturer. According to the manufacturer's instructions, samples with a cut-off index greater or equal to 1.0 were considered positive.

\subsubsection{Anti-RBD IgG assay}

Enzyme-linked immunosorbent assay (ELISA) plates (Corning Costar; cat. Nr. 3590) were coated overnight with His6-tagged RBD. Plates were blocked for $2 \mathrm{~h}$ at room temperature (RT) using blocking buffer (PBS + $1 \%$ BSA) and washed (wash buffer PBS $+0.002 \%$ Tween 80 ) six times.

148 Monoclonal anti-RBD calibrator antibody (Sino Biologicals; cat. Nr. 40150-D004) and serum 
medRxiv preprint doi: https://doi.org/10.1101/2022.01.17.22269081; this version posted January 17, 2022. The copyright holder for this preprint

(which was not certified by peer review) is the author/funder, who has granted medRxiv a license to display the preprint in perpetuity.

All rights reserved. No reuse allowed vithenthergaission vaccine monitoring in naive

\section{healthcare workers}

149 samples (diluted minimum 500-fold) were incubated for $2 \mathrm{~h}$ at RT (buffer PBS $+0.1 \%$ BSA + $150 \quad 0.002 \%$ Tween 80). After an additional washing step, goat antihuman (GAH) IgG conjugated with 151 horseradish peroxidase (HRP) was added (1:5000 dilution) and incubated for $1 \mathrm{~h}$ at RT. 152 Subsequently, washing was performed and the plate was developed using o-phenylenediamine 153 dihydrochloride (OPD; $0.4 \mathrm{~g} / \mathrm{L})$ and $\mathrm{H}_{2} \mathrm{O}_{2}(0.003 \%)$ in citrate buffer. After 30 min, the reaction 154 was stopped with $\mathrm{H}_{2} \mathrm{SO}_{4}(4 \mathrm{M})$. The absorbance was measured at $492 \mathrm{~nm}$ and the dose-response curve was analyzed by non-linear regression using GraphPad Prism 9.0.0 (Graph Software, San Diego, CA, USA). The assay was validated by measuring assay cut-off values for detection and quantification, accuracy, imprecision and dilutional linearity (33). Sample concentrations were determined using the anti-RBD calibrator antibody and WHO International Standard Serum (NIBSC ref 20-136) (34).

\subsubsection{Anti-N IgG assay}

The presence of serum anti-N IgG antibodies was determined via the Anti-SARS-CoV-2-NCP (IgG) enzyme immunoassay from EUROIMMUN on an ETI-Max 3000 instrument from DiaSorin. Samples that had a cut-of index greater or equal to 1.1 were considered positive as recommended by the instructions from the manufacturer.

\subsection{Antibody functionality: neutralization assay}

\subsubsection{In vitro neutralization assay}

Determination of the neutralizing capacity of the vaccine-induced antibodies was generated using the EUROIMMUN SARS-CoV-2 NeutraLISA assay according to the manufacturer's instructions. Samples were diluted 1:5 in sample buffer. A photometric measurement was made on a wavelength of $450 \mathrm{~nm}$ together with a reference wavelength of $620 \mathrm{~nm}$. Semiquantitative results were generated by calculating a ratio of the extinction values of the sample over the mean extinction value of the blank (measured in duplicate) and were presented as percentage inhibition. Percentage inhibition values lower than 20 were defined as negative, between 20 and 35 as borderline and higher or equal to 35 as positive. Lot-specific control concentrates (positive and negative) were used as assay references.

\subsubsection{Vesicular stomatitis virus (VSV) pseudovirus neutralization assay}

VSV S-pseudotypes were generated as described previously (35). Briefly, HEK-293T cells (SARS-CoV-2) were transfected with the respective $S$ protein expression plasmids, and one day later infected $(\mathrm{MOI}=2$ ) with green fluorescent protein $(\mathrm{GFP})$-encoding VSV $\Delta \mathrm{G}$ backbone virus (purchased from Kerafast). Two hours later, the medium was replaced by medium containing antiVSV-G antibody (I1-hybridoma, ATCC CRL-2700) to neutralize residual VSV-G input. After 24 $\mathrm{h}$ incubation at $32{ }^{\circ} \mathrm{C}$, the supernatants were harvested. To quantify neutralizing antibodies

183 (nAbs), serial dilutions of serum samples were incubated for $1 \mathrm{~h}$ at $37{ }^{\circ} \mathrm{C}$ with an equal volume of S pseudotyped VSV particles and inoculated on Vero E6 cells ( SARS-CoV-2) for $18 \mathrm{~h}$.

The percentage of GFP expressing cells was quantified on a Cell Insight CX5/7 High Content (v.6.6.0) software. Neutralization IC50 values were determined by normalizing the serum 188 neutralization dilution curve to a virus (100\%) and cell control (0\%) and fitting in GraphPad Prism 
medRxiv preprint doi: https://doi.org/10.1101/2022.01.17.22269081; this version posted January 17, 2022. The copyright holder for this preprint

(which was not certified by peer review) is the author/funder, who has granted medRxiv a license to display the preprint in perpetuity.

All rights reserved. No reuse allowed vithentherg2 252 vaccine monitoring in naive

\section{healthcare workers}

189 (inhibitor vs. response, variable slope, four parameters model with top and bottom constraints of $190100 \%$ and $0 \%$ respectively).

\section{$191 \quad 2.4$ Stimulation of SARS-CoV-2 specific T cells}

192 Heparinized whole blood was used for the EUROIMMUN SARS-CoV-2 interferon gamma release assay (IGRA) kit that was executed according to the manufacturer's instructions adapted as described below (Supplementary Figure 1). Heparinized whole blood was transferred into three different tubes (BLANK, COV2 and STIM) followed by an incubation step for 20-24 h at $37( \pm 1)$ ${ }^{\circ} \mathrm{C}$ after inverting 6 times. Following incubation, the tubes were centrifuged at RT for $10 \mathrm{~min}$ at 700 g. Approximately $200 \mu \mathrm{L}$ of stimulated heparinized plasma from each tube was pipetted into Eppendorf tubes and centrifuged again at RT for $10 \mathrm{~min}$ at 12,000 g. Finally, the supernatant was pipetted into cryovials and stored at $-20{ }^{\circ} \mathrm{C}$ until measurement via the EUROIMMUN Quant-TCell ELISA (interferon- $\gamma$ (IFN- $\gamma$ ) ELISA). Importantly, the pellet containing the cellular fraction was used for additional flowcytometry (see 2.5.2 $\mathrm{T}$ cell phenotyping and activity).

\subsubsection{Interferon $\gamma($ IFN- $\gamma)$ ELISA}

204

Specific SARS-CoV-2 induced IFN- $\gamma$ release was determined via the EUROIMMUN Quant-TCell ELISA according to the manufacturer's instructions. A photometric measurement was performed at a wavelength of $450 \mathrm{~nm}$ with a reference measurement at $620 \mathrm{~nm}$. For each tube, IFN- $\gamma$ concentrations were determined using a standard curve that was fitted via GraphPad Prism (four parameters model without restrictions). Then, for each subject, the determined IFN- $\gamma$ concentration from the unstimulated control (BLANK) was subtracted from the determined IFN- $\gamma$ concentrations of both the stimulation control (STIM) and SARS-CoV-2 stimulated condition (COV2). Lot-specific lyophilized calibrators and controls were used as a standard.

\subsection{Flowcytometric analyses}

\subsubsection{Circulating RBD specific $B$ cells}

213 Thawed PBMCs were stained with a selective B cell staining panel that is listed in Supplementary

214 Table 1. After a final washing step, the pellets were resuspended in $300 \mu \mathrm{L} \mathrm{dPBS}$ and immediately

215 acquired on the flowcytometer (FACSVerse device, BD Biosciences, USA).

Living B cells were selected from the PBMC pool via a CD3 $/$ CD $19^{+} /$Zombie $^{-}$gating strategy (Supplementary Figure 2A). Specific B cell reactivity against SARS-CoV-2 was assessed with wild type RBD-biotin and PE-streptavidin. Within each sample, a negative control tube (without RBD-biotin) was included to correct for sample-specific background. For each staining experiment, a sample with documented RBD specific B cells was used as a positive control for quality assessment.

\subsection{2 $\mathrm{T}$ cell phenotyping and activity}

The remaining cell pellet from the IGRA tubes (see 2.4 Stimulation of SARS-CoV-2 specific T cells) was immediately resuspended with dPBS in a total volume of $500 \mu \mathrm{L}$. A whole blood staining was performed on the reconstituted samples. In summary, $\mathrm{T}$ cell staining (Supplementary Table 1) was performed in $150 \mu \mathrm{L}$ of the reconstituted samples. Following incubation for $30 \mathrm{~min}$ at $4{ }^{\circ} \mathrm{C}$, $3 \mathrm{~mL}$ of red blood cell (RBC) lysis buffer (BD FACS ${ }^{\mathrm{TM}}$ lysing solution, BD Biosciences, USA) was added for $5 \mathrm{~min}$ at RT to allow RBC lysis. After extensive washing, the pellets were 
medRxiv preprint doi: https://doi.org/10.1101/2022.01.17.22269081; this version posted January 17, 2022. The copyright holder for this preprint

(which was not certified by peer review) is the author/funder, who has granted medRxiv a license to display the preprint in perpetuity.

All rights reserved. No reuse allowed vithent1 16252 ission vaccine monitoring in naive

\section{healthcare workers}

229 resuspended in $350 \mu \mathrm{L}$ dPBS and immediately acquired on the flowcytometer. T cells were selected 230 via gating (Supplementary Figure $2 \mathrm{~B}$ ) on the $\mathrm{CD}^{+}$population and further divided into helper $\mathrm{T}$ 231 cells $\left(\mathrm{T}_{\mathrm{H}} ; \mathrm{CD}^{+} / \mathrm{CD}^{-}\right)$, circulating follicular helper $\mathrm{T}$ cells $\left(\mathrm{T}_{\mathrm{CFH}} ; \mathrm{CD}^{+} / \mathrm{CD}^{-} / \mathrm{CXCLR}^{\mathrm{hi}}\right)$ and 232 cytotoxic $\mathrm{T}$ cells $\left(\mathrm{T}_{\mathrm{C}} ; \mathrm{CD}^{-} / \mathrm{CD}^{+}\right)$. Membrane markers used to asses $\mathrm{T}$ cell activation were $\mathrm{CD} 40 \mathrm{~L}$ and CD69. The gating strategy was based on the fluorescence minus one (FMO) signal retrieved for each individual fluorochrome. For each subject, besides the condition with SARS-CoV-2 specific antigens, an unstimulated negative (BLANK) and a positive control (STIM) condition

236 were available to respectively correct for background and to assess intrinsic cell functionality.

\section{$237 \quad 2.6 \quad$ Viral whole genome sequencing}

238 RNA extraction was performed by using the DEXR-15-LM96 kit for automated extraction (Diagenode, Seraing, Belgium) with $350 \mu \mathrm{L}$ sample input. Extracted RNA was eluted from magnetic beads in $50 \mu$ of UltraPure DNase/RNasefree distilled water. Following RNA extraction, cDNA was synthesized followed by multiplex PCR amplification using a modified version of the ARTIC V3 LoCost protocol with the Midnight primer set (1200 bp amplicons). The libraries were sequenced on a MinION using R9.4.1 flow-cells (Oxford Nanopore Technologies, Oxford, UK) and MinKnow software v21.02.1. The resulting fast5 reads were basecalled and demultiplexed using Guppy v5.0.16 in super accuracy mode. Genome assembly was performed using the ARTIC bioinformatics pipeline v1.1.3, which entails adapter trimming, mapping to the reference strain Wuhan-Hu-1 (MN908947), as previously described (36).

\section{$248 \quad 2.7 \quad$ Statistical analyses}

249 Statistical analysis was performed using both Microsoft Excel (version 365 for Windows, 250 Microsoft Corporation, USA) and GraphPad Prism (version 9.0.0 for Windows, GraphPad 251 Software, USA). Flowcytometric data was processed using FCS Express (version 7 research edition

252 for Windows, De Novo Software, USA). Continuous variables were presented as mean \pm standard deviation if the Shapiro-Wilk normality test was successful or as either median \pm interquartile range (IQR) or median with the interval between quartile 1 and 3 (Q1-Q3) if not. Confidence intervals (Cl) of medians were calculated via the standard method described by Zar JH (37). Discrete and categorical variables were shown as respectively numbers or categories with percentages between brackets. Comparison between parameters was done using a student t-test or one-way ANOVA with a post-hoc correction for multiple comparisons via Tukey's test and after assessment of constant variance using Levene's test if normality was met or with the respective non-parametric alternatives when not. Paired analyses were done if appropriate. Correlation between parameters was assessed via bivariate analysis expressed via a Pearson determination coefficient $\left(\mathrm{R}^{2}\right)$; a Pearson $r$ or via a Spearman $r$ if there was no normality and also via a multivariate analysis using principal component analysis (PCA). For all tests, the significance was set at a two-tailed probability level of 0.05 .

\section{Results}

\subsection{Trial characteristics and exclusions}

267 All enrolled healthcare workers $(\mathrm{N}=32)$ were Caucasian and exact half of them were women. The 268 age ranged between 25 and 51 years with a mean of $36 \pm 7$ (95\% confidence interval (CI): 33-38) 269 years. During this trial, one subject was excluded for all analyses because she dropped out between 


\section{healthcare workers} natural SARS-CoV-2 infection. For both timepoints, the anti-N IgG titers remained below the index value with a mean of $0.022 \pm 0.038$ and $0.100 \pm 0.113$ at respectively $t_{\text {pre }}$ and $t_{3 m}$.

\section{3}

A

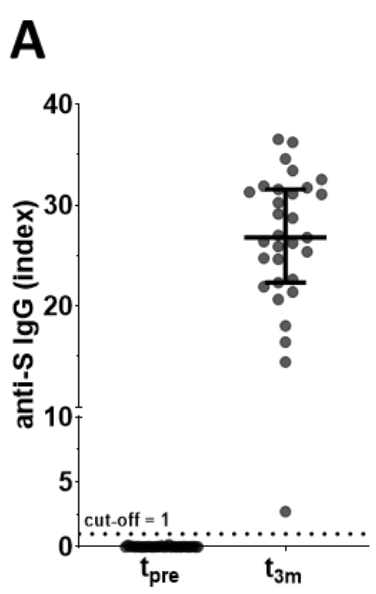

B

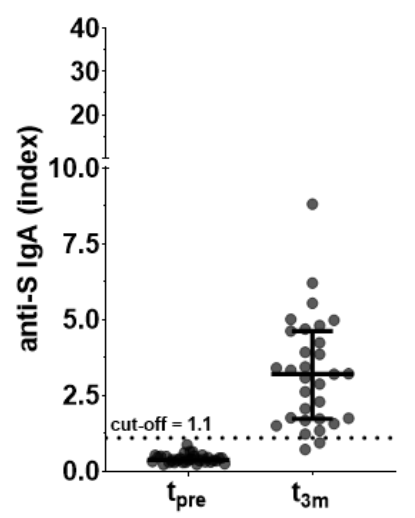

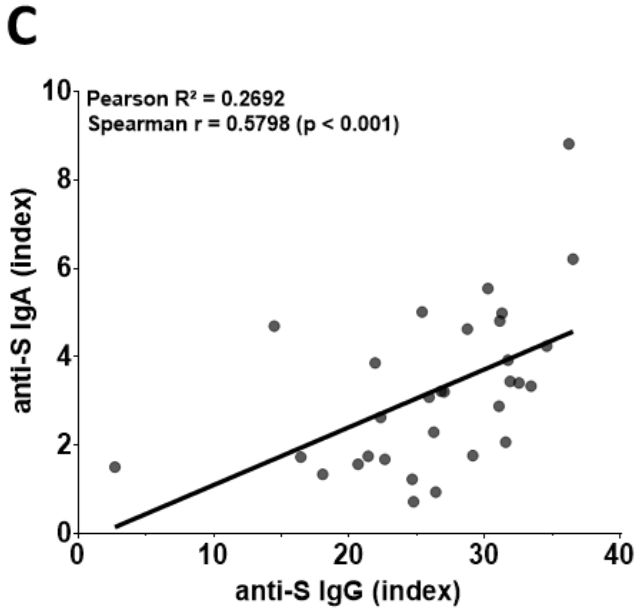

279

280

281

282

283

284

285

286

287

288

289

290

291

292

293

294

295

\subsection{Antibody and B cell response three months after BNT162b2 vaccination}

\subsubsection{BNT162b2 vaccination induces functionally active antibodies}

Three months after BNT162b2 vaccination, the vaccine-induced antibody response was described via both serology and in vitro neutralization assays. Spike-specific antibodies are represented in Figure 2.

Figure 2. SARS-CoV-2 anti-S serology $(\mathbf{N}=\mathbf{3 1})$. (A) anti-S IgG titers, (B) anti-S IgA titers and (C) simple linear regression and correlation between anti-S IgG and IgA antibodies 3 months after BNT162b2 vaccination. Error bars represent median with IQR. Abbreviations: $S=$ spike, pre = baseline sampling moment before vaccination, $3 \mathrm{~m}=3$ months after baseline, IQR = interquartile range.

At baseline, all 31 subjects were negative for both anti-S IgG and IgA with a median index titer of $0.010 \pm 0.020$ (95\% CI: 0.000-0.020) and 0.371 \pm 0.194 (95\% CI: 0.320-0.474) respectively. Three months after vaccination, all individuals showed detectable anti-S IgG antibodies with a median index titer of $26.8 \pm 9.23$ (95\% CI: 24.7-31.1) of which two of these individuals had no anti-S IgA response (Figure 2A-B). Anti-S IgG and IgA titers were moderately but significantly correlated with a Spearman $r$ of 0.5798 ( $p<0.001$ ) and a Pearson $R^{2}$ of 0.2692 (Figure 2C).

Next, anti-RBD IgG titers were determined (Figure 3A). In line with the above findings, no antiRBD IgG antibodies could be detected at baseline ( $<160 \mathrm{BAU} / \mathrm{mL})$, whereas all but one had antiRBD IgG titers three months post-vaccination with a median titer of 827.0 (95\% CI: 661.0-1103) with a Q1-Q3 interval of 599.0-1310 BAU/mL. 


\section{healthcare workers}
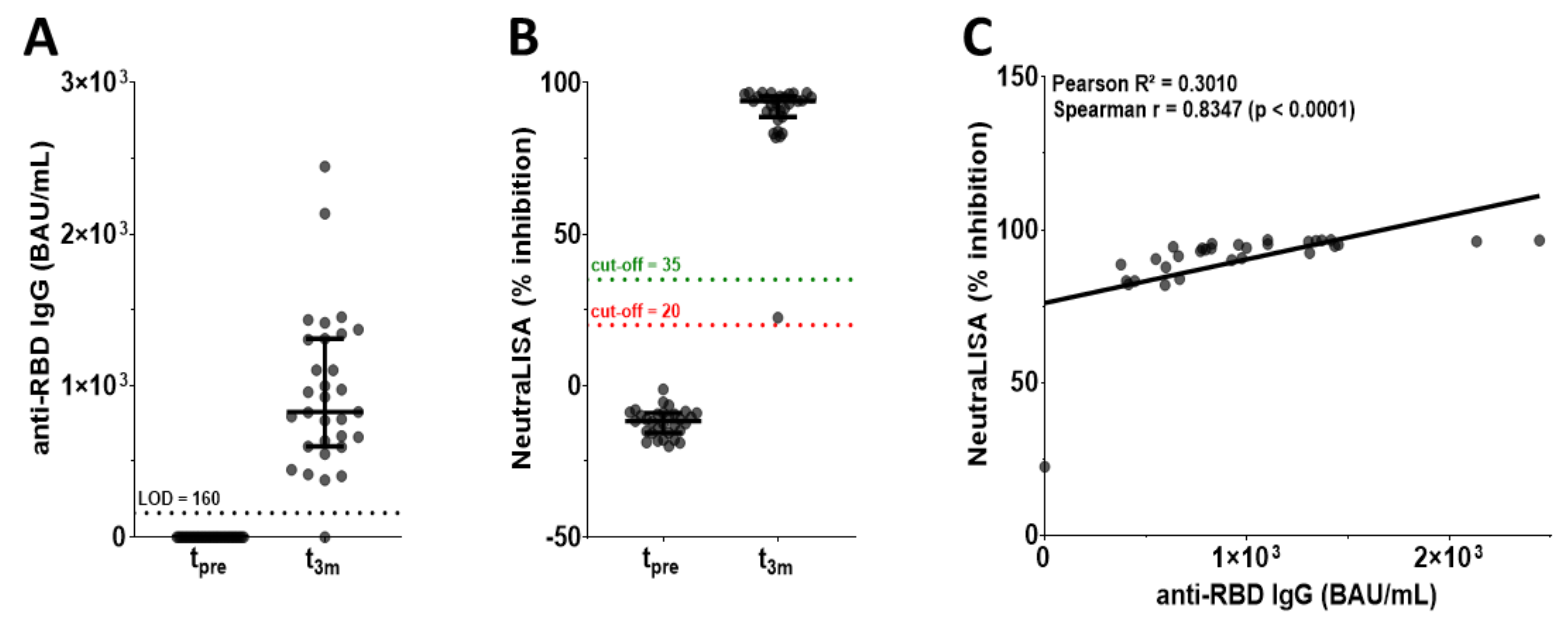
between anti-RBD IgG and antibody functionality at three months post-BNT162b2 vaccination. Error bars represent median with IQR. Abbreviations: $\mathrm{RBD}=$ receptor-binding domain, pre $=$ baseline sampling moment before vaccination, $3 \mathrm{~m}=3$ months after baseline, IQR = interquartile range.

Additionally, the capacity of the induced antibodies to neutralize the binding between wild type functionality with a Spearman $r$ of 0.8347 ( $\mathrm{p}<0.0001$ ) and a Pearson $\mathrm{R}^{2}$ of 0.3010 (Figure 3C).

\subsubsection{Circulating RBD specific B cells}

311 In parallel to the assessment of serology and functionality of the vaccine-induced antibodies, the precursor rate of circulating RBD specific B cells was examined. For each individual, a PBMC aliquot of $t_{p r e}$ and $t_{3 m}$ were analyzed within the same experiment to allow the detection of vaccinespecific changes. An example of the gating strategy used for the flowcytometric B cell phenotyping is shown in Supplementary Figure 2A.

The magnitude of $\mathrm{CD}^{-} / \mathrm{CD} 19^{+} \mathrm{B}$ cells was comparable between both timepoints and ranged between $1.93-14.16 \%$ of gated lymphocytes. Furthermore, a small $(0.087 \pm 0.068 \%$ of parent, i.e. living B cells) but significant ( $\mathrm{p}<0.005)$ population of circulating RBD specific B cells was detected in 10 of the 31 individuals (32.26\%) at three months post vaccination (Figure 4A). Within these 10 subjects, the rate of circulating RBD specific B cells showed a significant good correlation 
medRxiv preprint doi: https://doi.org/10.1101/2022.01.17.22269081; this version posted January 17, 2022. The copyright holder for this preprint (which was not certified by peer review) is the author/funder, who has granted medRxiv a license to display the preprint in perpetuity.

All rights reserved. No reuse allowed witholthermission

\section{healthcare workers}

and a moderate correlation with antibody functionality (Pearson $\mathrm{R}^{2}=0.3398$, Spearman $\mathrm{r}=0.8902$ with $\mathrm{p}<0.005$, Figure 4C).
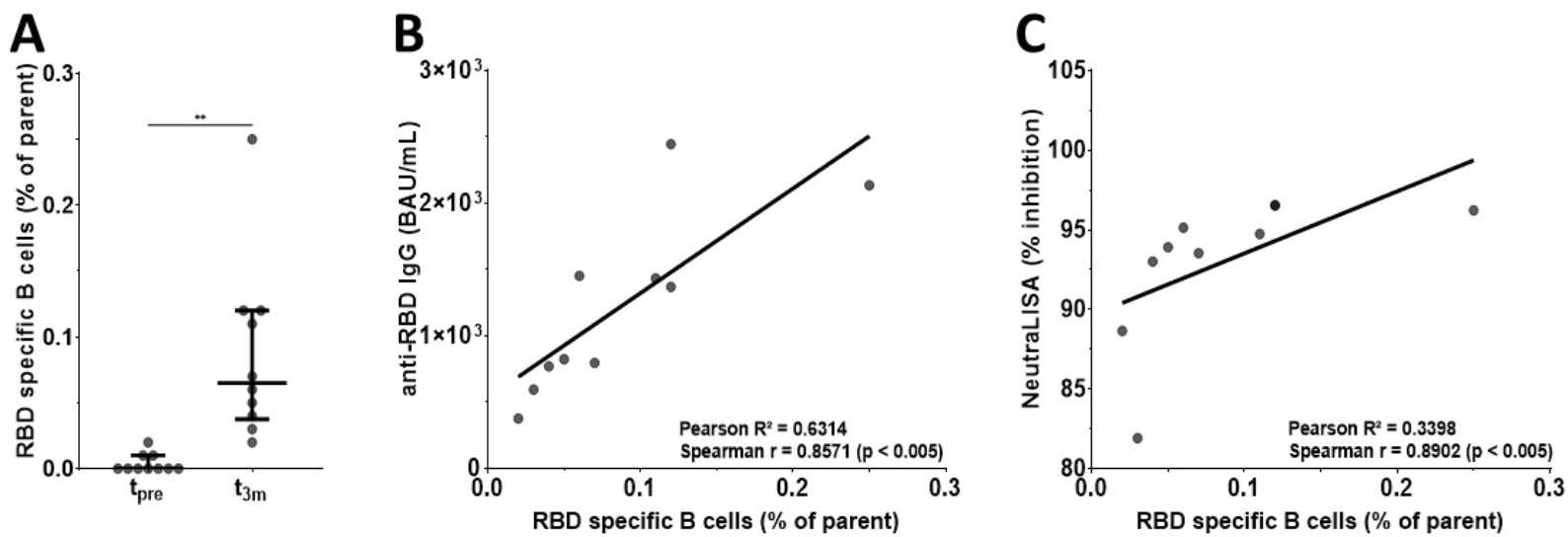

325

326

327

328

329

330

331

332

333

334

335

336

337

338

339

340

341

342

343

344

Figure 4. Flowcytometric determination of both $B$ cell phenotype and rate of circulating RBD specific B cells. (A) Scatter plot representing the circulating RBD specific B cell populations that were found in 10 participants. Each data point represents the percentage of RBD specific B cells after subtraction of the sample-specific background (i.e. condition with RBD-biotin minus condition without RBD-biotin). ** Wilcoxon test: $\mathrm{p}<0.01$. (B) Simple linear regression and correlation between anti-RBD IgG and circulating RBD specific B cells found in 10 participants at three months post-BNT162b2 vaccination. (C) Simple linear regression and correlation between antibody functionality and circulating RBD specific B cells found in 10 participants at three months post-BNT162b2 vaccination. Error bars represent median \pm IQR. Abbreviations: RBD = receptorbinding domain, pre $=$ baseline sampling moment before vaccination, $3 \mathrm{~m}=3$ months after baseline, $\mathrm{IQR}=$ interquartile range.

\subsection{T cell immune response three months after BNT162b2 vaccination}

\subsubsection{BNT162b2 vaccination induces $\mathrm{SARS}-\mathrm{CoV}-2$-specific IFN- $\gamma$ production by $\mathrm{T}$ cells}

Next, we also defined the SARS-CoV-2 specific T cell response. Firstly, we assessed the vaccineinduced specific IFN- $\gamma$ release by T cells upon restimulation with SARS-CoV-2 antigens (Figure 5). Three subjects were excluded from these analyses due to technical issues. 
healthcare workers

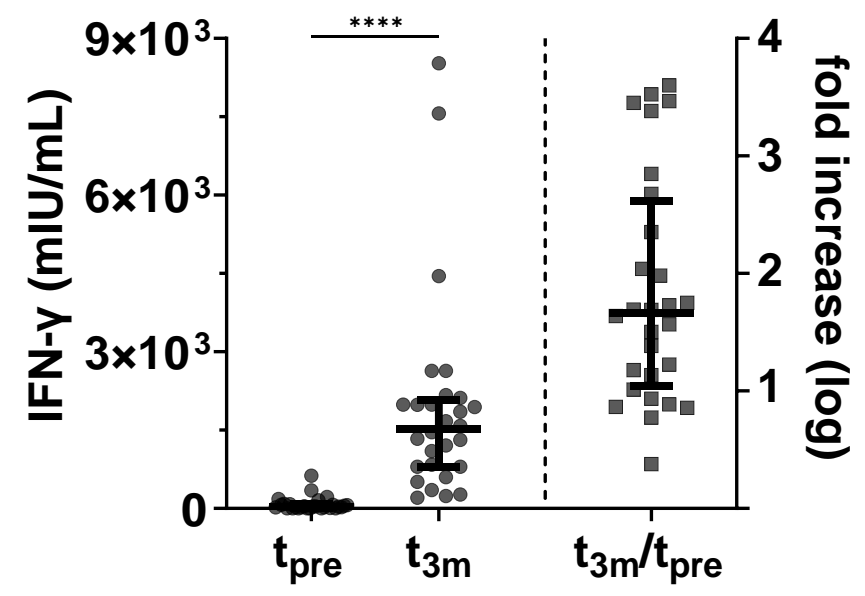

Figure 5. SARS-CoV-2 specific $\mathbf{T}$ cell mediated IFN- $\gamma$ release $(\mathbf{N}=\mathbf{2 8})$. Scatter plot representing the SARS-CoV-2 specific IFN- $\gamma$ release after subtraction of the unstimulated negative control at both baseline and 3 months after vaccination. The right part of the plot shows the subject-specific fold increase in SARS-CoV-2 specific IFN- $\gamma$ release. $* * * *$ Wilcoxon test: $p<0.0001$. Error bars represent median $\pm \mathrm{IQR}$. Abbreviations: IFN- $\gamma=$ interferon $-\gamma$, pre $=$ baseline sampling moment before vaccination, $3 \mathrm{~m}=3$ months after baseline, IQR $=$ interquartile range.

The median SARS-CoV-2-specific T cell mediated IFN- $\gamma$ release post vaccination was $1520 \pm$ $1287 \mathrm{mIU} / \mathrm{mL}$ (95\% CI: 836.5-1986) with values ranging between 204.8 and $8523 \mathrm{mIU} / \mathrm{mL}$. These IFN- $\gamma$ values were significantly higher $(\mathrm{p}<0.0001)$ compared to baseline values (median: $34.77 \pm$ $73.50 \mathrm{mIU} / \mathrm{mL}$ ). Three months post vaccination, there was at least a three-fold increase of SARSCoV-2-specific T cell mediated IFN- $\gamma$ release detected and even exceeding 10,000-fold for some participants. At both timepoints, there was a clear IFN- $\gamma$ release observed in the stimulation control condition (data not shown).

\subsubsection{SARS-CoV-2-specific CD4 and CD8 T cells display an activated phenotype after BNT162b2 vaccination}

Using the reconstituted cell pellets from the IGRA tubes, we were able to include $\mathrm{T}$ cell phenotyping in addition to the SARS-CoV-2 specific IFN- $\gamma$ release. An example of the applied gating strategy can be retrieved in Supplementary Figure 2B. In accordance with the B cell phenotyping, the magnitudes of $\mathrm{CD}^{+}$lymphocytes (i.e. T cells), $\mathrm{CD} 4 / \mathrm{CD}^{+}$cytotoxic $\mathrm{T}$ cells $\left(\mathrm{T}_{\mathrm{C}}\right.$ ), $\mathrm{CD}^{+} / \mathrm{CD}^{-}$helper $\mathrm{T}$ cells $\left(\mathrm{T}_{\mathrm{H}}\right)$ and $\mathrm{CD}^{+} / \mathrm{CD} 8^{-} / \mathrm{CXCR} 5^{\text {hi }}$ circulating follicular $\mathrm{T}$ helper cells $\left(\mathrm{T}_{\mathrm{CFH}}\right)$ were similar for all three conditions within the IGRA (data not shown).

368 Three months after vaccination, a significant upregulation of the early activation marker CD69 was 369 detected upon SARS-CoV-2 specific restimulation in the $\mathrm{T}_{\mathrm{C}}(\mathrm{p}<0.0001), \mathrm{T}_{\mathrm{H}}(\mathrm{p}<0.0001)$ and $370 \mathrm{~T}_{\mathrm{CFH}}(\mathrm{p}<0.005)$ cell subsets (Figure 6A). Furthermore, CD40L was also significantly upregulated 371 in both $\mathrm{T}_{\mathrm{H}}(\mathrm{p}<0.0001)$ and $\mathrm{T}_{\mathrm{CFH}}(\mathrm{p}<0.005)$ subsets (Figure 7A). For each sample, a condition 372 with mitogenic stimulation was analyzed as well as means of quality control (data not shown). 


\section{healthcare workers}
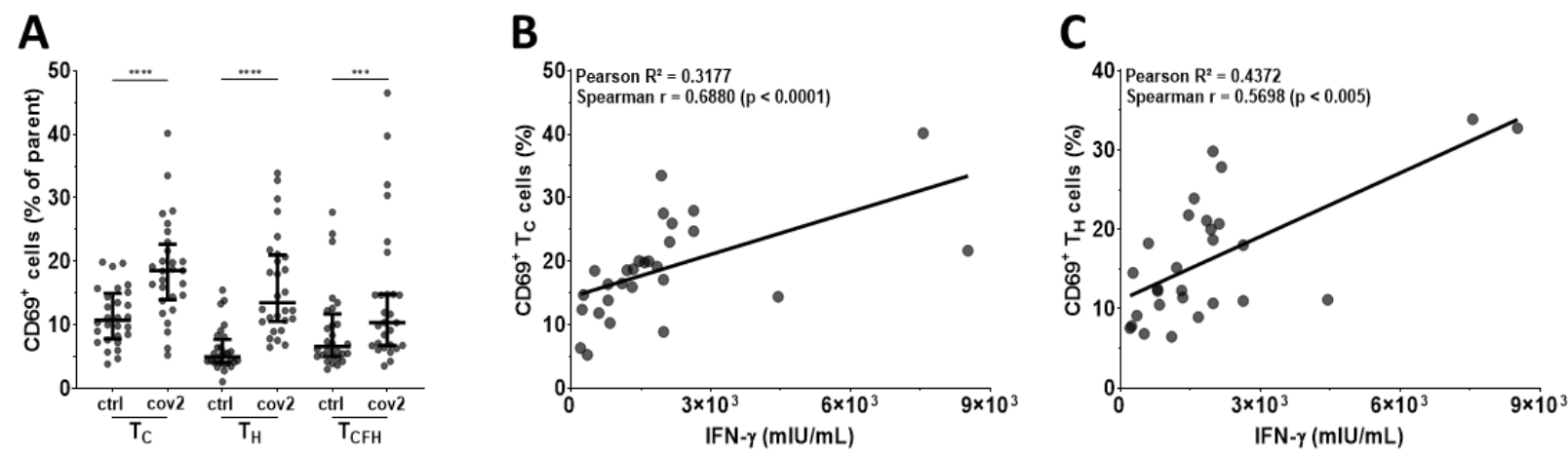

Figure 6. Expression of activation marker CD69 on SARS-CoV-2 specific $T$ cells after BNT162b2 vaccination $(\mathbf{N}=\mathbf{2 8})$. (A) Scatter plot showing the percentages of CD69 ${ }^{+} \mathrm{T}_{\mathrm{C}}, \mathrm{T}_{\mathrm{H}}$ and $\mathrm{T}_{\mathrm{CFH}}$ cells present in the condition without stimulation (ctrl) and after SARS-CoV-2 specific stimulation $(\operatorname{cov} 2)$. $* * * *$ Wilcoxon test: $\mathrm{p}<0.0001$, $* * *$ Wilcoxon test: $\mathrm{p}<0.005$. (B-C) Simple linear regression and correlation between SARS-CoV-2 specific T cell mediated IFN- $\gamma$ release and following parameters of cellular immunity: (B) percentage of $\mathrm{CD} 9^{+} \mathrm{T}_{\mathrm{C}}$ cells and $(\mathbf{C})$ percentage of $\mathrm{CD} 9^{+} \mathrm{T}_{\mathrm{H}}$ cells. Error bars represent median \pm IQR. Abbreviations: IFN $-\gamma=$ interferon $-\gamma$, pre $=$ baseline sampling moment before vaccination, $3 \mathrm{~m}=3$ months after baseline, IQR $=$ interquartile range.

SARS-CoV-2 specific T cell mediated IFN- $\gamma$ release was moderately but significantly correlated with both $\mathrm{CD}^{+} 9^{+}$on $\mathrm{T}_{\mathrm{C}}$ (Pearson $\mathrm{R}^{2}=0.3177$, Spearman $\mathrm{r}=0.6880$ with $\mathrm{p}<0.0001$; Figure 6B) and $\mathrm{T}_{\mathrm{H}}$ (Pearson $\mathrm{R}^{2}=0.4372$, Spearman $\mathrm{r}=0.5698$ with $\mathrm{p}<0.005$; Figure $6 \mathrm{C}$ ) and $\mathrm{CD}^{2} \mathrm{LL}^{+}$
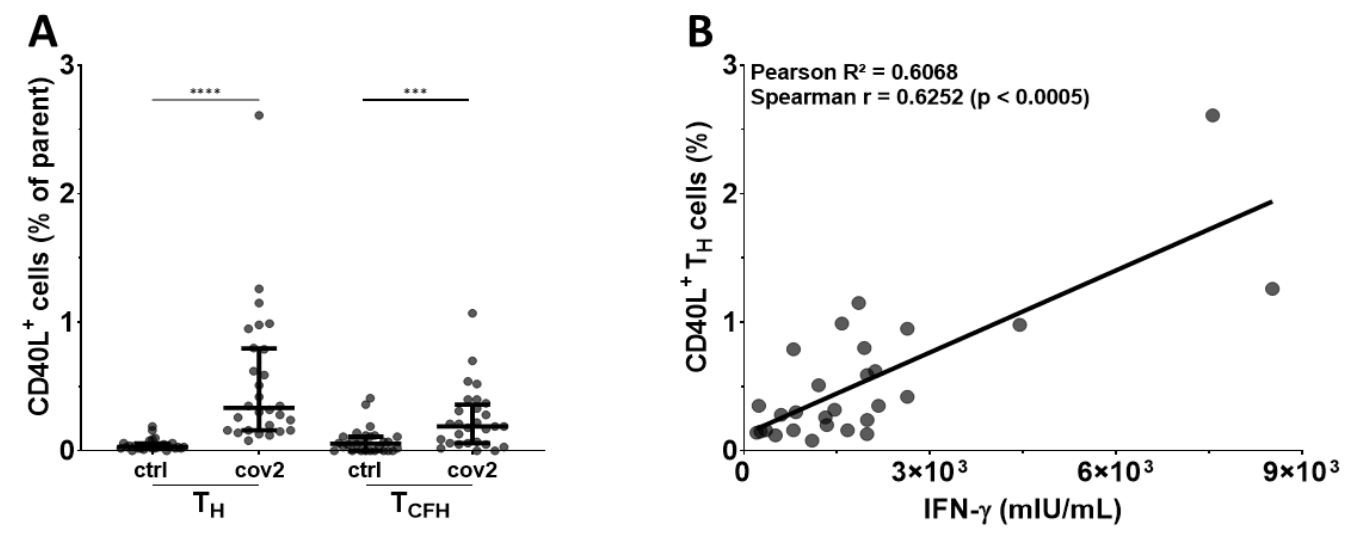

391 Figure 7. Expression of costimulatory molecule CD40L on SARS-CoV-2 specific T cells after 


\section{healthcare workers}

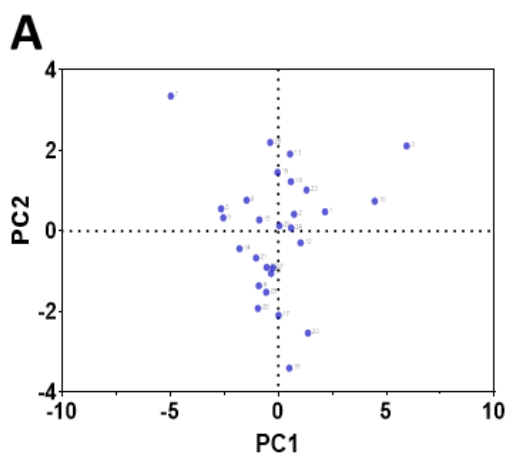
$\mathrm{IQR}=$ interquartile range .
$\mathrm{T}_{\mathrm{CFH}}$ cells present in the condition without stimulation (ctrl) and after SARS-CoV-2 specific stimulation (cov2). $* * * *$ Wilcoxon test: $\mathrm{p}<0.0005,{ }^{* * *}$ Wilcoxon test: $\mathrm{p}<0.005$. (B) Simple linear regression and correlation between SARS-CoV-2 specific T cell mediated IFN- $\gamma$ release and percentage of $\mathrm{CD}_{40 \mathrm{~L}^{+}} \mathrm{T}_{\mathrm{H}}$ cells. Error bars represent median $\pm \mathrm{IQR}$. Abbreviations: IFN- $\gamma=$ interferon- $\gamma$, pre $=$ baseline sampling moment before vaccination, $3 \mathrm{~m}=3$ months after baseline,

\subsection{The magnitudes of $B$ and $T$ cell response are not correlated three months after BNT162b2 vaccination}

Finally, we aligned the magnitude of the different SARS-CoV-2 specific B and T cell parameters but no significant linear relations nor correlations could be observed (Pearson $\mathrm{R}^{2}<0.15$ and Spearman $r<0.40$ with $p>0.10$ in all cases). Also, within the 10 healthcare workers that had circulating RBD specific B cells, the precursor rate was not correlated either with CD69 activated (Spearman $r=0.0426, p>0.50$ ) or CD40L activated T cells (Spearman $r=0.1398, p>0.50$ ). Additionally, PCA was performed to identify parameters that contribute most to the overall variance found within this cohort (Figure 8).

Figure 8. Principal component analysis between parameters of both vaccine-induced 412 humoral and cellular responses $(\mathbf{N}=\mathbf{2 8}$ ). (A) PC scores plot, (B) loadings plot and (C) proportions of variance graph. Abbreviations: $\mathrm{PCA}=$ principal component analysis, $\mathrm{PC}=$ principal component.

First, no clear clustering could be identified from the PC scores plot (Figure 8A). Next, PCA revealed that the loadings of all 11 included variables (circulating RBD specific B cells were excluded) appeared on the same side of the loadings plot, showing that each variable correlated positively with PC 1 . Also, two different clusters could be identified based on the loadings plot with PC 2 (Figure 8B). Combining PC 1 and PC 2 explained approximately $60 \%$ of the overall 
medRxiv preprint doi: https://doi.org/10.1101/2022.01.17.22269081; this version posted January 17, 2022. The copyright holder for this preprint (which was not certified by peer review) is the author/funder, who has granted medRxiv a license to display the preprint in perpetuity. All rights reserved. No reuse allowed usthothermission

\section{healthcare workers}

\subsection{Symptomatic SARS-CoV-2 BTI despite a vaccine-induced functional antibody response and specific $T$ cell immunity}

424 Within the timeframe of this study, one subject experienced a RT-PCR confirmed symptomatic BTI. This BTI occurred within the collection period for the $t_{3 \mathrm{~m}}$ moment and was therefore redefined as the $t_{\text {ВтI }}$ timepoint for this participant. As described in Figure 1, a nasopharyngeal swab was collected additionally to the blood tubes drawn via venipuncture.

428 This case concerned a woman in her thirties who presented with general malaise, dry cough and dyspnea 46 days after receiving the booster vaccine. The subject was ill for seven days but without the need for hospitalization. Based on the WHO COVID-19 severity score (38), the subject was classified as experiencing a mild SARS-CoV-2 infection. A few days prior to the BTI, this participant reported to have been in close contact with a hospitalized COVID-19 patient. A complete overview of both the humoral and cellular immune parameters at the $t_{\mathrm{BTI}}$ timepoint of this subject are listed in Table 1.

435 Table 1. Summary of both humoral and cellular parameters of the subject with symptomatic 436 BTI.

\begin{tabular}{|c|c|c|}
\hline Parameter & BTI & $\begin{array}{c}\text { Range: minimum to maximum } \\
\text { (based on values of other subjects) }\end{array}$ \\
\hline $\begin{array}{l}\text { Anti-S IgG } \\
\text { (index) }\end{array}$ & 36.23 & $2.720-36.53$ \\
\hline $\begin{array}{l}\text { Anti-RBD IgG } \\
(\mathrm{IU} / \mathrm{mL})\end{array}$ & 1370 & $<160.0-2446$ \\
\hline $\begin{array}{l}\text { Anti-S IgA } \\
\text { (index) }\end{array}$ & 8.814 & $0.719-8.814$ \\
\hline $\begin{array}{l}\text { Anti-N IgG } \\
\text { (index) }\end{array}$ & 0.126 & $0.031-0.666$ \\
\hline $\begin{array}{l}\text { In vitro neutralization } \\
\text { (percentage inhibition) }\end{array}$ & 96.54 & $22.44-96.67$ \\
\hline $\begin{array}{l}\text { VSV pseudovirus neutralization * } \\
(\text { SNT50) }\end{array}$ & 584 & NA \\
\hline $\begin{array}{l}\text { Circulating RBD specific B cells } \\
(\%)\end{array}$ & 0.12 & $0.02-0.25$ \\
\hline $\begin{array}{l}\text { IFN- } \gamma \text { release } \\
(\mathrm{mIU} / \mathrm{mL})\end{array}$ & 2806.63 & $204.800-8523.00$ \\
\hline $\begin{array}{l}\mathrm{CD}^{+} 9^{+} \mathrm{T}_{\mathrm{C}} \text { cells } * * \\
(\%)\end{array}$ & 14.40 & $5.240-40.15$ \\
\hline $\begin{array}{l}\mathrm{CD} 69^{+} \mathrm{T}_{\mathrm{H}} \text { cells } * * \\
(\%)\end{array}$ & 11.13 & $6.470-33.88$ \\
\hline $\begin{array}{l}\mathrm{CD} 69^{+} \mathrm{T}_{\mathrm{CFH}} \text { cells } * * \\
(\%)\end{array}$ & 9.88 & $3.56-45.61$ \\
\hline $\begin{array}{l}\mathrm{CD} 40 \mathrm{~L}^{+} \mathrm{T}_{\mathrm{H}} \text { cells } * * \\
(\%)\end{array}$ & 0.98 & $0.08-2.61$ \\
\hline $\begin{array}{l}\mathrm{CD} 40 \mathrm{~L}^{+} \mathrm{T}_{\mathrm{CFH}} \text { cells } * * \\
(\%)\end{array}$ & 0.022 & $0.000-1.070$ \\
\hline
\end{tabular}


medRxiv preprint doi: https://doi.org/10.1101/2022.01.17.22269081; this version posted January 17, 2022. The copyright holder for this preprint

(which was not certified by peer review) is the author/funder, who has granted medRxiv a license to display the preprint in perpetuity.

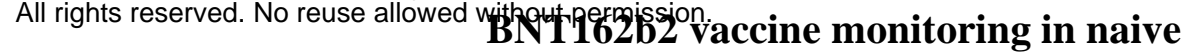

\section{healthcare workers}

* This neutralization assay was performed with the D614G mutant strain of SARS-CoV-2. ** These values are taken from the condition with specific stimulation of the T cells with SARS-CoV2 peptides. Abbreviations: $\mathrm{BTI}=$ breakthrough infection, $\mathrm{S}=$ spike, $\mathrm{N}=$ nucleocapsid, $\mathrm{RBD}=$ receptor-binding domain, $\mathrm{VSV}=$ vesicular stomatitis virus, IFN- $\gamma=$ interferon- $\gamma, \mathrm{NA}=$ not applicable.

In summary, at time of presenting with a symptomatic BTI, this participant displayed a functional serological response (both in vitro neutralization and in pseudovirus assay) as well as SARS-CoV2 specific T-cell reactivity. Moreover, a population of circulating RBD specific B cells could be observed. In order to investigate whether this BTI could be ascribed to any of the currently known VoC, whole viral genome sequencing was performed on the nasopharyngeal swab. Genome sequencing revealed the presence of the B.1.1.7 Pango lineage, which is also known as the alpha VoC.

\section{Discussion}

In this study, we report on SARS-CoV-2 specific B and T cell immunity in healthcare workers in a supraregional hospital in Belgium three months after BNT162b2 vaccination. Importantly, during this study, both the number of occupied hospital and intensive care beds increased substantially defining the start of the so-called third SARS-CoV-2 infection wave in Belgium (from 15 February 2021 onwards) (39). Besides increasing virus circulation, also the emergence of multiple VoC, including alpha (B.1.1.7), beta (B.1.351) and gamma (P1) variants are known to boost infection rates, in particular since vaccination coverage in the general population was still low at that time $(14,40)$.

Serological findings in this cohort were comparable with those described by other groups that studied the serology status post booster BNT162b2 vaccination at different timepoints, i.e. ranging between 2 and 12 weeks post primary vaccination (41-48). Of note, many of these studies monitored vaccine induced antibody responses in patients suffering from a myriad of pathologies (41-43). In addition, the net effect of vaccination is often difficult to highlight as in many studies subjects with earlier natural SARS-COV-2 infection are not excluded $(27,49)$. Three months post vaccination, spike-specific IgA levels were less pronounced compared to IgG levels, the latter observed in all participants of our cohort. A more rapid waning of SARS-CoV-2 IgA antibodies compared to IgG was reported by Wisnewski et al (50). A significant but moderate correlation between spike-specific IgG and IgA was observed, which was in line with findings by other groups (50-52). However, the key question here is in fact not the net level of antigen specific vaccineinduced antibodies, but whether these antibodies are truly protective and thus able to neutralize docking of SARS-CoV-2 virus particles to the human ACE-2 receptor on target cells. Indeed, nAbs that were able to almost completely block the RBD binding to human ACE- 2 could be retrieved in all but one participant, confirming the high efficacy rate of the BNT162b2 vaccine after three months. In line with the findings by others $(50,52,53)$, both anti-S and anti-RBD IgG titers were identified as moderate correlates for antibody functionality. Of note, the borderline in vitro neutralization observed in one subject could not be attributed to assay-specific technical issues, as a similar result was observed in an in-house developed test (data not shown). With both IgG and IgA anti-S antibodies just above detection limit, either the mRNA-vaccine encoded spike protein 
medRxiv preprint doi: https://doi.org/10.1101/2022.01.17.22269081; this version posted January 17, 2022. The copyright holder for this preprint

(which was not certified by peer review) is the author/funder, who has granted medRxiv a license to display the preprint in perpetuity.

All rights reserved. No reuse allowed withotherks 25 vaccine monitoring in naive

\section{healthcare workers}

479

480

481

482

483

484

485

486

487

488

489

490

491

492

493

494

495

496

497

498

499

500

501

502

503

504

505

506

507

508

509

510

511

512

513

514

515

516

517

518

519

520

521

522

523

is less immunogenic in this subject or antibody titers - and most likely also functionality - are decreasing more rapidly. In an environment with high virus circulation, including VoC, this person could be more at risk to develop a BTI. Overall, our findings add to high neutralization efficacy of the BNT162b2 vaccine reported by others at earlier timepoints $(51,54)$. Of note, binding and neutralization assays were performed with the Wuhan variant of SARS-CoV-2 encoded by the BNT162b2 vaccine. In other words, one might show high antibody titers and functional neutralization to the original virus strain that could prove to be biologically less relevant against the mutated target proteins of the emergent $\mathrm{VoC}$.

Currently, there is not yet much information available concerning the dynamics and longevity of humoral immunity upon SARS-CoV-2 vaccination. Circulating antigen specific B cells are considered to be a surrogate marker for the resident antigen specific B cells present within the secondary lymphoid organs that are essential to establish B cell memory (18,55-57). Interestingly and opposite to findings by Ciabattini et al. (18), circulating RBD specific B cells were only detectable in one third of the study participants at 3 months post vaccination. In line with the latter, we were only able to retrieve RBD specific B cells in a fraction of convalescent patients (Imbrechts et al., submitted), again in contrast with findings by others such as the group of Nussenzweig et al (48). Of the 10 individuals that displayed circulating RBD specific B cell clones, a correlation was observed between the abundance of RBD-specific B cells on the one hand and both serology and antibody functionality on the other hand (Figure 4B-C). As no signs of ongoing natural infection were found, these data suggest that at least in these participants, the germinal center driven humoral immunity is still being built up three months post mRNA vaccination. Shifting viewpoint from vaccination to COVID-19 treatment options, our findings suggest that PBMCs from vaccinated donors could serve as a source to sort out RBD specific B cell clones able to produce strong nAbs of therapeutic interest. This technique has already been performed with PBMCs from convalescent individuals and already led to the development of several promising nAbs (e.g. LY-CoV555 (58), REGN10933 and REGN10987 (59), ABBV-2B04 (60), TY027 (61) and 3B8 (Imbrechts et al. submitted)) of which some are being evaluated in phase III trials or are already approved by the FDA.

Specific T cell responses upon BNT162b2 vaccination were already documented in the original phase I/II trial by Sahin et al $(24,25)$. In addition, other groups reported a SARS-CoV-2 specific IFN- $\gamma$ release in either immunocompromised patients $(41,62,63)$, dialysis patients $(45,64)$ or healthcare workers at different timepoints up to four weeks post vaccination $(7,27,28)$. In line with these results, we could clearly observe SARS-CoV-2 specific IFN- $\gamma$ release in all subjects up to three months post vaccination. Moreover, we were able to include T cell phenotyping as secondary read-out to the whole blood IGRA, hereby eliminating the need for PBMCs nor expensive peptide pools covering the most prominent MHC haplotypes in a given population. Using this approach, we were able to show SARS-CoV-2 specific activation of both $\mathrm{T}_{\mathrm{C}}$ and $\mathrm{T}_{\mathrm{H}}$ cell subsets which implies that the SARS-CoV-2 specific antigens in this assay were presented on both MHC class I and II proteins respectively. This was also shown in reports from both Braun et al. (65) and Giminez et al. (66) in which they used a related SARS-CoV-2 antigen pool to stimulate T cells and found respectively an upregulation of activated $\mathrm{CD}^{+}$and $\mathrm{CD}^{+} \mathrm{T}$ cells. Besides membrane expression of CD69 as general early T cell activation marker, we were able to show upregulation of CD40L both in total $\mathrm{T}_{\mathrm{H}}$ and in the $\mathrm{CXCR} 5^{+} \mathrm{T}_{\mathrm{CFH}}$ subsets. Both early $\mathrm{T}$ cell activation and membrane CD40L expression are correlated with the release of type II interferon, confirming that BNT162b2 vaccination induces a $\mathrm{T}_{\mathrm{H} 1}$ response (25). In addition, as CD40L is one of the key costimulatory 
medRxiv preprint doi: https://doi.org/10.1101/2022.01.17.22269081; this version posted January 17, 2022. The copyright holder for this preprint

(which was not certified by peer review) is the author/funder, who has granted medRxiv a license to display the preprint in perpetuity.

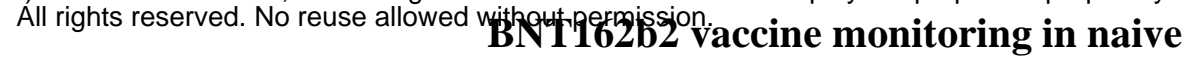

\section{healthcare workers}

524 molecules involved in both antibody class switching and BCR affinity maturation (55), CD40L expression on $\mathrm{T}_{\mathrm{H}}$ and in particular on CXCR5+ $\mathrm{T}_{\mathrm{CFH}}$ (47) suggests that in vivo antigen re-exposure will most likely lead to a massive and rapid $\mathrm{T}$ cell dependent antibody recall response, the latter being exactly the overall goal of vaccination.

Next, we addressed whether the humoral and cellular immune parameters measured in this study were associated to each other. From the PCA analysis, two different clusters could be identified based on the loadings plot with PC 2. Interestingly, these clusters included all the parameters determined within B or T cell immunity. This suggests that measuring only one or two parameters from both the humoral and cellular immune response is sufficient to respectively predict 60 to 80 percent of the overall variability observed in this cohort (Figure 8C). Also, the approximate angle of 90 degrees between both clusters emphasizes the absence of any correlation between each other.

Within the three month monitoring time window in this cohort, there was one subject who developed a mild symptomatic BTI (incidence of $3.22 \%$ ) although the incidence rate reported in the BNT162b2 phase III trial was very low $(<0.05 \%, 8$ cases out of 18,198$)(67)$. Of note, one must be careful not to overinterpret this high incidence rate due to the small size of this study. In addition, healthcare workers might be more at risk than the general population, especially during a new infection wave including emergent VoC. Although, it must be mentioned that a recently published report of the Belgian Healthcare Knowledge Center - that included surveillance data since the start of the vaccination campaign in Belgium - mentioned that the national incidence of symptomatic BTI within the general population (of which $71.2 \%$ were vaccinated with Comirnaty ${ }^{\circledR}$ ) was only $0.20 \%$ (68). Antonelli et al. stated that vaccinated people who developed a BTI had mostly milder symptoms and were approximately half less likely to report symptoms of Long COVID-19 Syndrome than infected unvaccinated people (69). This was also the case in our subject as she had a mild infection and recovered completely after seven days. Interestingly, this subject showed a clear vaccine-induced immune response including SARS-CoV-2 specific T cell activity, positive titers of both anti-S and anti-RBD IgG antibodies with a high neutralization efficacy (confirmed in an established pseudovirus assay) and had a small but clearly detectable population of circulating RBD specific B cells. Here, the latter could very well represent the recall response to natural infection in this subject. Whole genome sequencing retrieved that the subject was infected with the alpha variant which was at that time the upcoming VoC within the first phase of the third wave in Belgium. Antibody repertoire profiling of the subject with BTI compared to a pool of age and gender matched controls could yield interesting information, in particular when compared to other vaccine BTI profiles.

At last, it must be noted that this trial has several limitations. Firstly, the number of subjects is rather limited and was based on a power analysis for the serological and IFN- $\gamma$ release read-outs. Hence, this design is less suited to pick up rather unexpected events such as BTI. Larger studies that look at both arms of the adaptive immune response months after vaccination are needed to further finetune our findings and to characterize BTI more reliable. Secondly, only SARS-CoV-2 naive individuals were included in this study. The pronounced recall response due to vaccination in convalescent individuals has been described and even led to the discussion whether these individuals should receive one rather than two vaccine doses. Addressing this was beyond our scope as we specifically aimed to study the BNT162b2 vaccine-induced de novo immune response

5672 variants leads the binding and neutralization assays available at any given time. In this 
medRxiv preprint doi: https://doi.org/10.1101/2022.01.17.22269081; this version posted January 17, 2022. The copyright holder for this preprint

(which was not certified by peer review) is the author/funder, who has granted medRxiv a license to display the preprint in perpetuity.

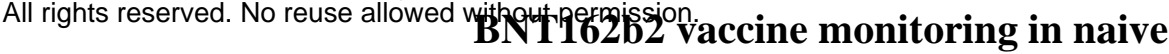

\section{healthcare workers}

568 perspective, running neutralization assays with VoC RBD could give deeper insights in the breadth 569 of the vaccine-induced functional immunity. Finally, long-term sustainability of the vaccine570 induced immune response can only be truly considered when looking even beyond the three month 571 timepoint. This will be particularly relevant as we are slowly progressing from a global pandemic

572 state to a genuine endemic circulation of the SARS-CoV-2 virus.

\section{Conclusion}

574 Three months post BNT162b2 mRNA vaccination, previously naive healthcare workers show

575 functional but individually distinct humoral and cellular immune responses to SARS-CoV-2 that 576 do not guarantee protection against the emerging VoC.

\section{Conflict of Interest}

578 The authors ZD and KD declare a possible conflict of interest as they are employees of the Institut 579 für Experimentelle Immunologie affiliated to EUROIMMUN Medizinische Labordiagnostika AG 580 (Lübeck, Germany). This company provided following materials for this study: EUROIMMUN 581 SARS-CoV-2 IGRA kit (no. ET 2606-3003), EUROIMMUN interferon-gamma ELISA (no. EQ 582 6841-9601), EUROIMMUN SARS-CoV-2 NeutraLISA (no. EI 2606-9601-4) and in-house 583 produced RBD-biotin.

\section{$584 \quad 7 \quad$ Author Contributions}

$585 \mathrm{BC}, \mathrm{NC}, \mathrm{MI}, \mathrm{NG}$ and $\mathrm{WM}$ contributed to the conception and design of the manuscript. BC, KC, $586 \mathrm{AV}, \mathrm{NC}, \mathrm{JVC}, \mathrm{XB}, \mathrm{MI}, \mathrm{NG}$ and WM contributed to the acquisition, analysis or interpretation of 587 data. $\mathrm{BC}, \mathrm{KC}, \mathrm{AV}, \mathrm{NC}, \mathrm{MI}, \mathrm{ZD}, \mathrm{KD}, \mathrm{KV}, \mathrm{NG}, \mathrm{SDM}$ and $\mathrm{WM}$ have drafted the work or 588 substantively revised it.

\section{$589 \quad 8 \quad$ Funding}

$590 \quad$ Internal KU Leuven funding

\section{Acknowledgments}

592 The authors would like to thank the people from BIOGNOST CV, Heule (Belgium) for their 593 support.

\section{$594 \quad 10 \quad$ References}

595 1. WHO. World Health Organization: Coronavirus [Internet]. 2021. Available from:

596 https://www.who.int/health-topics/coronavirus\#tab=tab_1

597 2. Corman VM, Landt O, Kaiser M, Molenkamp R, Meijer A, Chu DKW, et al. Detection of 5982019 novel coronavirus (2019-nCoV) by real-time RT-PCR. Eurosurveillance. 2020 Jan $599 \quad 23 ; 25(3): 2000045$.

600 3. Zhang Y-Z. Novel 2019 coronavirus genome - SARS-CoV-2 coronavirus - Virological 601 [Internet]. Virological.org. 2020. p. 1-7. Available from: https://virological.org/t/novel602 2019-coronavirus-genome/319 
medRxiv preprint doi: https://doi.org/10.1101/2022.01.17.22269081; this version posted January 17, 2022. The copyright holder for this preprint

(which was not certified by peer review) is the author/funder, who has granted medRxiv a license to display the preprint in perpetuity.

All rights reserved. No reuse allowed withow 116262 vaccine monitoring in naive

\section{healthcare workers}

603 4. OMS. IHR Emergency Committee on Novel Coronavirus (2019-nCoV) [Internet]. Geneva,

604 Switzerland. 2020. p. 1-4. Available from: https://www.who.int/director-

605

606 general/speeches/detail/who-director-general-s-statement-on-ihr-emergency-committee-

607 on-novel-coronavirus-(2019-ncov)

5. Romani G, Dal Mas F, Massaro M, Cobianchi L, Modenese M, Barcellini A, et al. Population Health Strategies to Support Hospital and Intensive Care Unit Resiliency during the COVID-19 Pandemic: The Italian Experience. Popul Health Manag. 2021 Apr $1 ; 24(2): 174-81$.

611 6. FDA. Pfizer-BioNTech COVID-19 Vaccine Public Assessment Report. 2021.

612 7. EMA - Committee for Medicinal Products for Human Use. Pfizer-BioNTech COVID-19

$613 \quad$ Vaccine EMA Public Assesment Report. 2021.

614 8. EMA - Committee for Medicinal Products for Human Use. Moderna COVID-19 Vaccine

$615 \quad$ EMA Public Assessment Report. 2021.

616 9. FDA. Moderna COVID-19 Vaccine Public Assessment Report. 2021.

617 10. EMA - Committee for Medicinal Products for Human Use. AstraZeneca EMA Public 618 Assessment Report. Vol. 31. 2021.

619 11. EMA - Committee for Medicinal Products for Human. COVID-19 Vaccine Janssen EMA $620 \quad$ Public Assessment Report. Vol. 31. 2021.

621 12. FDA. Janssen COVID-19 Vaccine Public Assesment Report. 2021.

13. Study of mRNA Vaccine Formulation Against COVID-19 in Healthy Adults 18 Years of Age and Older - Full Text View - ClinicalTrials.gov [Internet]. 2021. Available from: https://clinicaltrials.gov/ct2/show/NCT04904549?term=sanofi+gsk\&cond=SARS-CoV$2 \&$ draw $=2 \&$ rank $=1$

14. WHO. Tracking SARS-CoV-2 Variants [Internet]. WHO. 2021. p. 1-13. Available from:

15. Otto SP, Day T, Arino J, Colijn C, Dushoff J, Li M, et al. The origins and potential future Jul 26;31(14):R918-29.

635 17. Bettini E, Locci M. SARS-CoV-2 mRNA Vaccines: Immunological mechanism and 636 beyond. Vaccines. 2021 Feb 1;9(2):1-20.

637 18. Ciabattini A, Pastore G, Fiorino F, Polvere J, Lucchesi S, Pettini E, et al. Evidence of 638 SARS-CoV-2-Specific Memory B Cells Six Months After Vaccination With the 


\section{healthcare workers}

BNT162b2 mRNA Vaccine. Front Immunol. 2021 Sep 28;12:3751.

19. Forgacs D, Jang H, Abreu RB, Hanley HB, Gattiker JL, Jefferson AM, et al. SARS-CoV-2 mRNA Vaccines Elicit Different Responses in Im Duration of antiviral immunity after smallpox vaccination. Nat Med. 2003 Sep 1;9(9):1131-7.

21. Kedzierska K, Koutsakos M. The ABC of major histocompatibility complexes and T cell receptors in health and disease. Viral Immunol. 2020 Apr 1;33(3):160-78.

22. Gil-Manso S, Carbonell D, López-Fernández L, Miguens I, Alonso R, Buño I, et al. Induction of High Levels of Specific Humoral and Cellular Responses to SARS-CoV-2 After the Administration of Covid-19 mRNA Vaccines Requires Several Days. Front

23. Lombardi A, Bozzi G, Ungaro R, Villa S, Castelli V, Mangioni D, et al. Mini Review Preliminary Results. Vol. 12, Frontiers in Immunology. Frontiers Media S.A.; 2021. p.

24. Mulligan MJ, Lyke KE, Kitchin N, Absalon J, Gurtman A, Lockhart S, et al. Phase I/II study of COVID-19 RNA vaccine BNT162b1 in adults. Nature. 2020 Aug 12;586(7830):589-93.

25. Sahin U, Muik A, Derhovanessian E, Vogler I, Kranz LM, Vormehr M, et al. COVID-19 vaccine BNT162b1 elicits human antibody and TH1 T cell responses. Nature. 2020 Sep 30;586(7830):594-9.

26. Vogel AB, Kanevsky I, Che Y, Swanson KA, Muik A, Vormehr M, et al. BNT162b

27. Casado JL, Haemmerle J, Vizcarra P, Rodriguez-Dominguez M, Velasco T, Velasco H, et breakthrough cases: A nation-wide retrospective longitudinal multiple cohort analysis using individualised data. EBioMedicine. 2021 Oct 1;72. 
medRxiv preprint doi: https://doi.org/10.1101/2022.01.17.22269081; this version posted January 17, 2022. The copyright holder for this preprint

(which was not certified by peer review) is the author/funder, who has granted medRxiv a license to display the preprint in perpetuity. All rights reserved. No reuse allowed withoutherbaission. vaccine monitoring in naive

\section{healthcare workers}

677

678

679

680

681

682

683

684

685

686

687

688

689

690

691

692

693

694

695

696

697

698

699

700

701

702

703

704

705

706

707

708

709

710

711

712

713

714

715

30. Blanquart F, Abad C, Ambroise J, Bernard M, Cosentino G, Giannoli JM, et al. Characterisation of vaccine breakthrough infections of sars-cov-2 delta and alpha variants and within-host viral load dynamics in the community, france, june to july 2021. Eurosurveillance. 2021 Sep 16;26(37).

31. Tene Y, Levytskyi K, Adler A, Halutz O, Paran Y, Goldshmidt H, et al. An outbreak of SARS-CoV-2 infections among hospital personnel with high mRNA vaccine uptake. Infect Control Hosp Epidemiol. 2021

32. Bahl A, Johnson S, Maine G, Garcia MH, Nimmagadda S, Qu L, et al. Vaccination reduces need for emergency care in breakthrough COVID-19 infections: A multicenter cohort study. Lancet Reg Heal - Am. 2021 Sep;100065.

33. EMA. Committee for Medicinal Products for Human Use. Guideline on bioanalytical method validation. EMEA/CHMP/EWP/192217/2009 Rev 1 Corr 2** [Internet]. 2012;123. Available from: www.ema.europa.eu/contact

34. NIBSC NI for BS andControls. WHO International Standard First WHO International Standard for anti-SARS-CoV-2 immunoglobulin (human) NIBSC code: 20/136 Instructions for use (Version 2.0, Dated 17/12/2020) [Internet]. 2020. Available from: http://www.nibsc.org/standardisation/international_standards.aspx

35. Sanchez-Felipe L, Vercruysse T, Sharma S, Ma J, Lemmens V, Van Looveren D, et al. A single-dose live-attenuated YF17D-vectored SARS-CoV-2 vaccine candidate. Nature. 2021 Feb 11;590(7845):320-5.

36. Van Cleemput J, van Snippenberg W, Lambrechts L, Dendooven A, D’Onofrio V, Couck $\mathrm{L}$, et al. Organ-specific genome diversity of replication-competent SARS-CoV-2. Nat Commun. 2021 Nov 16;12(1):1-11.

37. Zar JH. Biostatistical Analysis. 5th ed. 2010.

38. Diaz, Janet; Appiah, John; Askie, Lisa; Baller, April; Banerjee, Anshu; Barkley, Shannon; Bertagnolio, Silvia; Hemmingsen, Bianca; Bonet, Mercedes; Cunningham J. COVID-19: Clinical management Living guidance [Internet]. World Health Organization. 2021. p. 81. Available from: https://www.who.int/publications/i/item/WHO-2019-nCoV-clinical-20211

39. Sciensano. Covid-19 Surveillance Frequently Asked Questions [Internet]. 2021. Available from: https://covid-19.sciensano.be/sites/default/files/Covid19/COVID19_FAQ_ENG_final.pdf

40. Baele G, Cuypers L, Maes P, Dellicour S, Keyaerts E, Wollants E, et al. Genomic surveillance of SARS-CoV-2 in Belgium [Internet]. Vol. 2021. 2021. Available from: https://www.uzleuven.be/nl/laboratoriumgeneeskunde/genomic-surveillance-sars-cov-2belgium

41. Amodio D, Ruggiero A, Sgrulletti M, Pighi C, Cotugno N, Medri C, et al. Humoral and Cellular Response Following Vaccination With the BNT162b2 mRNA COVID-19 Vaccine in Patients Affected by Primary Immunodeficiencies. Front Immunol. 2021 Oct 
medRxiv preprint doi: https://doi.org/10.1101/2022.01.17.22269081; this version posted January 17, 2022. The copyright holder for this preprint

(which was not certified by peer review) is the author/funder, who has granted medRxiv a license to display the preprint in perpetuity.

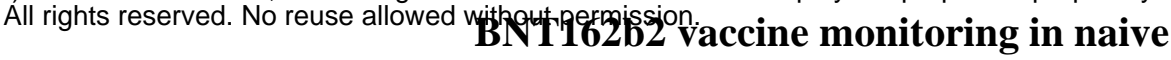

\section{healthcare workers}

$4 ; 12: 3947$.

42. Braun-Moscovici Y, Kaplan M, Braun M, Markovits D, Giryes S, Toledano K, et al. Disease activity and humoral response in patients with inflammatory rheumatic diseases after two doses of the Pfizer mRNA vaccine against SARS-CoV-2. Ann Rheum Dis. 2021 Oct 1;80(10):1317-21.

43. Achiron A, Mandel M, Dreyer-Alster S, Harari G, Magalashvili D, Sonis P, et al. Humoral immune response to COVID-19 mRNA vaccine in patients with multiple sclerosis treated with high-efficacy disease-modifying therapies. Ther Adv Neurol Disord. 2021;14.

44. Grupper A, Sharon N, Finn T, Cohen R, Israel M, Agbaria A, et al. Humoral response to the pfizer bnt162b2 vaccine in patients undergoing maintenance hemodialysis. Clin J Am Soc Nephrol. 2021 Jul 1;16(7):1037-42.

45. Zitt E, Davidovic T, Schimpf J, Abbassi-Nik A, Mutschlechner B, Ulmer H, et al. The Safety and Immunogenicity of the mRNA-BNT162b2 SARS-CoV-2 Vaccine in Hemodialysis Patients. Front Immunol. 2021 Jun 16;12:2390.

46. Lustig Y, Sapir E, Regev-Yochay G, Cohen C, Fluss R, Olmer L, et al. BNT162b2 COVID-19 vaccine and correlates of humoral immune responses and dynamics: a prospective, single-centre, longitudinal cohort study in health-care workers. Lancet Respir Med. 2021 Sep 1;9(9):999-1009.

47. Segundo DS, Comins-Boo A, Irure-Ventura J, Renuncio-García M, Roa-Bautista A, González-Lípez E, et al. Immune assessment of BNT162b2 m-RNA-spike based vaccine response in adults. Biomedicines. 2021 Aug 1;9(8).

48. Wang Z, Schmidt F, Weisblum Y, Muecksch F, Barnes CO, Finkin S, et al. mRNA vaccine-elicited antibodies to SARS-CoV-2 and circulating variants. Nature. $2021 \mathrm{Apr}$ 22;592(7855):616-22.

49. Hirotsu Y, Amemiya K, Sugiura H, Shinohara M, Takatori M, Mochizuki H, et al. Robust Antibody Responses to the BNT162b2 mRNA Vaccine Occur Within a Week After the First Dose in Previously Infected Individuals and After the Second Dose in Uninfected Individuals. Front Immunol. 2021 Aug 26;12:3457.

50. Wisnewski A V., Luna JC, Redlich CA. Human IgG and IgA responses to COVID-19 mRNA vaccines. PLoS One. 2021 Jun 1;16(6 June):e0249499.

51. Pratesi F, Caruso T, Testa D, Tarpanelli T, Gentili A, Gioè D, et al. Bnt162b2 mrna sarscov-2 vaccine elicits high avidity and neutralizing antibodies in healthcare workers. Vaccines. 2021 Jun 1;9(6).

52. Salvagno GL, Henry BM, Di Piazza G, Pighi L, De Nitto S, Bragantini D, et al. Anti-spike $\mathrm{s} 1$ iga, anti-spike trimeric igg, and anti-spike rbd igg response after bnt162b2 covid-19 mrna vaccination in healthcare workers. J Med Biochem. 2021;40(4):327-34.

53. Naaber P, Tserel L, Kangro K, Sepp E, Jürjenson V, Adamson A, et al. Dynamics of antibody response to BNT162b2 vaccine after six months: a longitudinal prospective 
medRxiv preprint doi: https://doi.org/10.1101/2022.01.17.22269081; this version posted January 17, 2022. The copyright holder for this preprint

(which was not certified by peer review) is the author/funder, who has granted medRxiv a license to display the preprint in perpetuity.

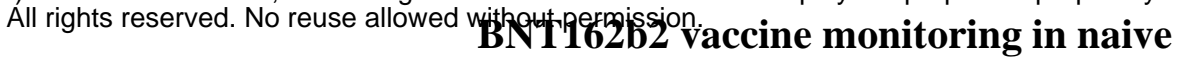

\section{healthcare workers}

755

756

757

758

759

760

761

762

763

764

765

766

767

768

769

770

771

772

773

774

775

776

777

778

779

780

781

782

783

784

785

786

787

788

789

790

study. Lancet Reg Heal - Eur. 2021 Sep;100208.

54. Favresse J, Gillot C, Di Chiaro L, Eucher C, Elsen M, Van Eeckhoudt S, et al. Neutralizing antibodies in covid-19 patients and vaccine recipients after two doses of bnt162b2. Viruses. 2021 Jul 1;13(7).

55. Byazrova M, Yusubalieva G, Spiridonova A, Efimov G, Mazurov D, Baranov K, et al. Pattern of circulating SARS-CoV-2-specific antibody-secreting and memory B-cell generation in patients with acute COVID-19. Clin Transl Immunol. 2021 Jan $1 ; 10(2): \mathrm{e} 1245$

56. Turner JS, O’Halloran JA, Kalaidina E, Kim W, Schmitz AJ, Zhou JQ, et al. SARS-CoV-2 mRNA vaccines induce persistent human germinal centre responses. Nature. 2021 Jun 28;596(7870):109-13.

57. Dan JM, Mateus J, Kato Y, Hastie KM, Yu ED, Faliti CE, et al. Immunological memory to SARS-CoV-2 assessed for up to 8 months after infection. Science. 2021 Feb 5;371(6529).

58. An EUA for Bamlanivimab - A Monoclonal Antibody for COVID-19. Vol. 325, JAMA Journal of the American Medical Association. JAMA; 2021. p. 880-1.

59. An EUA for Casirivimab and Imdevimab for COVID-19| The Medical Letter, Inc. [Internet]. 2021. Available from: https://secure.medicalletter.org/w1614a

60. Alsoussi WB, Turner JS, Case JB, Zhao H, Schmitz AJ, Zhou JQ, et al. A Potently Neutralizing Antibody Protects Mice against SARS-CoV-2 Infection. J Immunol. 2020 Aug 15;205(4):915-22.

61. NCT04649515. Efficacy and Safety of TY027, a Treatment for COVID-19, in Humans. https://clinicaltrials.gov/show/NCT04649515 [Internet]. 2020; Available from: https://clinicaltrials.gov/ct2/show/NCT04649515

62. Moyon Q, Sterlin D, Miyara M, Anna F, Mathian A, Lhote R, et al. BNT162b2 vaccineinduced humoral and cellular responses against SARS-CoV-2 variants in systemic lupus erythematosus. Ann Rheum Dis. 2021 Oct 4;annrheumdis-2021-221097.

63. Lasagna A, Agustoni F, Percivalle E, Borgetto S, Paulet A, Comolli G, et al. A snapshot of the immunogenicity, efficacy and safety of a full course of BNT162b2 anti-SARS-CoV-2 vaccine in cancer patients treated with PD-1/PD-L1 inhibitors: a longitudinal cohort study. ESMO Open. 2021 Oct;6(5):100272.

64. Van Praet J, Reynders M, De Bacquer D, Viaene L, Schoutteten M, Caluwé R, et al. Predictors and Dynamics of the Humoral and Cellular Immune Response to SARS-CoV-2 mRNA Vaccines in Hemodialysis Patients: A Multicenter Observational Study. J Am Soc Nephrol. 2021 Sep 29;ASN.2021070908.

65. Braun J, Loyal L, Frentsch M, Wendisch D, Georg P, Kurth F, et al. SARS-CoV-2-reactive T cells in healthy donors and patients with COVID-19. Nature. $2020 \mathrm{Jul}$ 29;587(7833):270-4. 
medRxiv preprint doi: https://doi.org/10.1101/2022.01.17.22269081; this version posted January 17, 2022. The copyright holder for this preprint

(which was not certified by peer review) is the author/funder, who has granted medRxiv a license to display the preprint in perpetuity.

\section{healthcare workers}

All rights reserved. No reuse allowed witholthermission, vaccine monitoring in naive

791

792

793

794

795

796

797

798

799

800

801

802

803

804
66. Giménez E, Albert E, Torres I, Remigia MJ, Alcaraz MJ, Galindo MJ, et al. SARS-CoV-2reactive interferon- $\gamma$-producing CD8+ T cells in patients hospitalized with coronavirus disease 2019. J Med Virol. 2021 Jan 1;93(1):375-82. /

67. European Medicines Agency. Comirnaty | European Medicines Agency [Internet]. Ema. 2021. Available from: https://www.ema.europa.eu/en/medicines/human/EPAR/comirnaty

68. Jespers V, Leroy R, Hulstaert F, Wyndham Thomas C, Van Montfort T, Van Damme UAntwerpen P, et al. Rapid Review of the Evidence on a COVID-19 Booster Dose After a Primary Vaccination Scheule Report for the Task Force Vaccination (Version With Summary in Dutch). 2021.

69. Antonelli M, Penfold RS, Merino J, Sudre CH, Molteni E, Berry S, et al. Risk factors and disease profile of post-vaccination SARS-CoV-2 infection in UK users of the COVID Symptom Study app: a prospective, community-based, nested, case-control study. Lancet Infect Dis. 2021 Sep 